\title{
Analysis of Windmild Rotation to Air Flow Rate in Shrimp Pond Aerator
}

\author{
Muhammad Aden Budi Ihtisan, Hasanudin, Oki Andrian Leonard Purba, Pebri Pratama \\ Tampubolon, Danan Aji Yulianto, Dandung Rudy Hartana \\ \{adenbi97@gmail.com¹, hasanrosmah@gmail.com², andrianleonard123@gmail.com³, \\ pebripratama0403@gmail.com ${ }^{4}$, dananyulianto45@yahoo.com ${ }^{5}$, dandungrudyhartana@yahoo.com $\left.{ }^{6}\right\}$ \\ Department of Machanical Engineering, Sekolah Tinggi Teknologi Nasional, Yogyakarta, \\ Indonesia ${ }^{1,2,3,4,5,6}$
}

\begin{abstract}
Aerator windmill made from plastic drum waste for aeration of shrimps' pond is designed in this paper. itis a kind of vertical axis windmill. Basically, It works to convert the kinetic energy of the wind into mechanical energy in rotational form into translational motion to drive the compressor. The compressor step is made in two different sizes $6 \mathrm{~cm}$ and $11 \mathrm{~cm}$. The aerator uses two compressors which each diameter of $3.81 \mathrm{~cm}$ in size. The results show that the air flow rate when the maximum wind speed of $4 \mathrm{~m} / \mathrm{s}$ with two compressors and $6 \mathrm{~cm}$ arm length is around $10255.5 \mathrm{~cm}^{3} /$ minute or $1,709 \times 10-4 \mathrm{~m}^{3} / \mathrm{s}$ while for $11 \mathrm{~cm}$ arm length is obtained $18802.5 \mathrm{~cm}^{3} /$ minute or $3,313 \times 10-4 \mathrm{~m}^{3} / \mathrm{s}$.
\end{abstract}

Keywords: windmild, compressor, aerator, air flow rate

\section{Introduction}

Aerators are kinds of application technology to supply oxygen into the water that they could be driven by electricity, fuel, and windmill to aeration the ponds. That many aerators are using in Indonesia today are driven by fuel and electricity which have disadvantages, such as high operational cost and rough maintenance, increasing shrimps stress because of heavy water flow, uneven of distributing oxygen supply and rotation of aerator vane could kill shrimps. Due to those conditions, this research concern to the design aerator windmill which blades were made from used plastic drums [1].

The effectiveness of the aeration process can reduce or eliminate pollutants in the water to the required limits, and is determined by the amount of air distribution in the pond. If the air distribution can be known, the effectiveness of the process can be estimated. The distribution of air in water is determined by the mechanism of the amount of air discharge coming out of the compressor, the longer and more frequently the compressor steps, the more dispersed air will be. The amount of pond area influences the need for air distribution needed, the wider the pond area, the more air distribution needs. So that the number of aerator tools used depends on the area of the pond. The optimal dissolved oxygen requirement is different depend on shrimp's species, for example for vaname shrimp is $4 \mathrm{ppm}$ with a tolerance limit higher than $0.8 \mathrm{ppm}$. The large number of waterwheels can result in a fairly strong flow or shock in the 
pond due to the movement of the waterwheel and can cause stress on the shrimp that are kept $[1]$.

Rotational speed of windmill and different arm length are very affected to the air flow rate that is resulted. Therefore, it is needed the mathematics model to easily determined air flow rate from shrimps' pond aerator by varying compressor steps and length of arms windmill. Only particular parts from a whole windmill parts were concerned in this paper. That windmill is used in this paper is a kind of vertical axis windmill that have $90 \mathrm{~cm}$ in diameter and consist of 4 blades each $100 \mathrm{~cm}$ in length. It is equipped by two compressors with $3.81 \mathrm{~cm}$ diameter size and different compressor steps each $6 \mathrm{~cm}$ and $11 \mathrm{~cm}$ in length as well. Wind speed is estimated by surrounding environment. Furthermore, analysis was doing to determine the air flow rate on shrimps' pond aerator.

Vertical axis windmill (savonius) configuration make it ideal for both rural and urban settings and offer the owner an opportunity to offset the rising cost of electricity and to preserve the environment [2].

\section{Methodology}

Research methodology is a scientific way to get data with specific goals and uses [3] The following is shown about the research methodology that we have done.

\subsection{Design System}

The first step is to design system of aerator windmill based on the best criteria which has chosen, such as: tower structure, axial structure of windmill, and etc. The design system was made is shown in Fig. 1.

Briefly explanation of each aerator windmill components describe in the following.

1. A Blade (vertical axis windmill) is a component that have functions to convert kinetic energy from the wind into mechanical energy to drive the compressor. The blade is made of plastic drum waste with a size that is $90 \mathrm{~cm}$ in height, 120 and $0.8 \mathrm{~cm}$ in diameter.

2. Function of transmission drive is to change rotation (rotation) to alternating motion (translation). The drive system consists of pulley, drive arm, lever triangle.

3. The compressor has function to compress air so that the air pressure increases. The number of compressors used is 2 pieces with $15 \mathrm{~cm}$ in length and of $3.81 \mathrm{~cm}$ in diameter.

4. Air-stabilizing tubes function in aerator windmill is to hold compressed air and stabilize airflow.

5. Pipe in this design system works to drain air from the air-stabilizing tube to the airstone.

6. Airstone serves to produce air bubbles so that oxygen is dissolved in water in shrimp pond.

7. The tower function is as a buffer for various aerator windmill components, such as blades, compressors, etc. The tower height is $4 \mathrm{~m}$ with the material made of $40 \times 40 \times 20 \mathrm{~A}$ angled iron and $20 \times 40 \times 2 \mathrm{~A}$ rectangular box pipe. It has four legs with fixed bases and by then it will be bolting to concrete foundation.

This aerator windmill is equipped by ladder that was integrated to the tower structure. It intends to easily maintenance the blades or replacing the blades. 


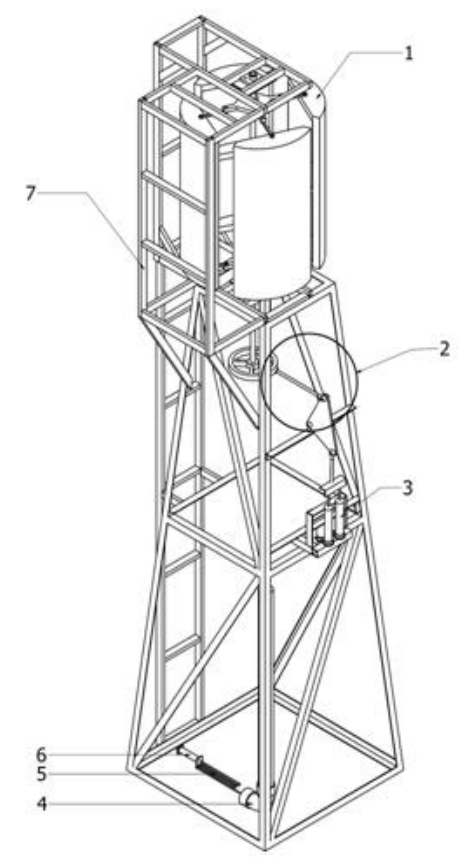

Annotation:

$$
\begin{aligned}
& 1 \text { : Blade (Vertical axis } 5 \text { : Pipe } \\
& \text { windmill) } \\
& \text { : Transmission Drive } 6 \text { : Airstone } \\
& 3 \text { : Compressor } 7 \text { : Tower } \\
& 4 \text { : Air-stabilizing Tube }
\end{aligned}
$$

Fig. 1. Design system of aerator windmill

\subsection{Implementation System}

Implementation system is next step to realization based on design system that have been done before. It is as product of technology resulted by research as shown in Fig. 1 with each components named on that figure.

As mention before that the base of the legs are bolted to concrete foundation so that it is not easy to falter. It is already shown in Fig. 1.

It is seen in Fig. 2 that the tower is galvanized by silver paint after first coated by anti-rust paint so that it is not easily to rust. The windmill is coated with blue paint as well as form of protection to the surrounding environment, another reason for aesthetics consideration. 


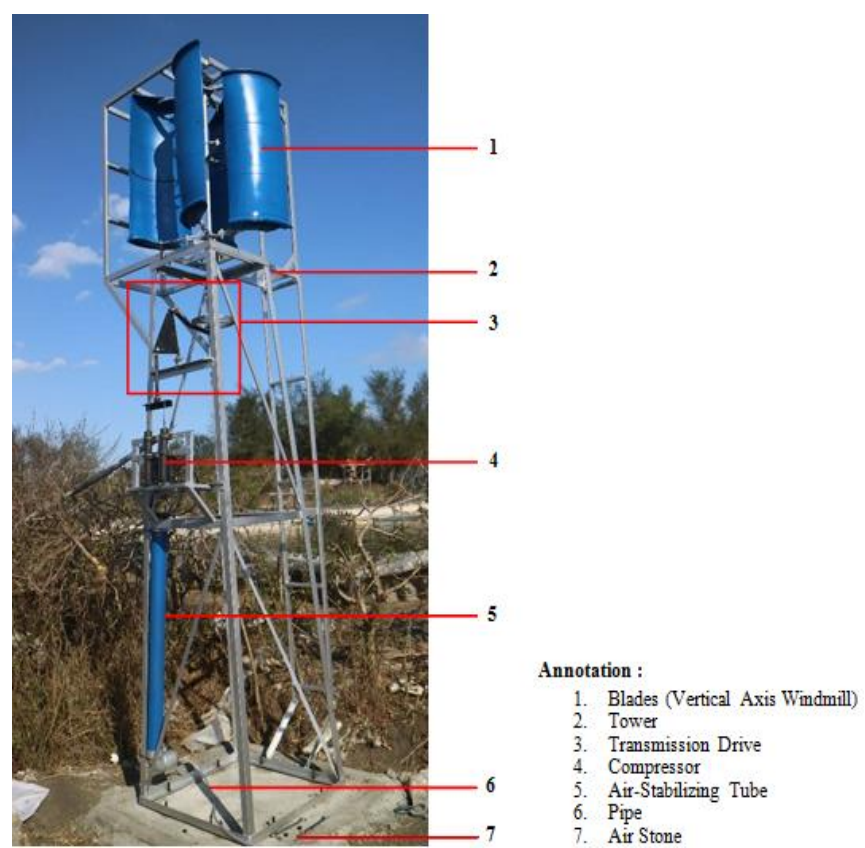

Fig 2. Implementation system. (Aerator Windmill)

\subsection{Data Measurement}

Data of wind speed dan air flow rate is needed for analysing requirement. Data acqusition is obtained by directly measurement in the field, that is in Dusun Kuwaru, Desa Poncosari, Kecamatan Srandakan, Kabupaten Bantul, Daerah Istimewa Yogyakarta as a partner whose place become our destination for apply our product design and technology research.

Fig. 1 shows the documentation when we have been doing data measurement.

Wind speed dan rotational windmill data are measured by Hot Wire Anemometer and Digital Tachometer [3].
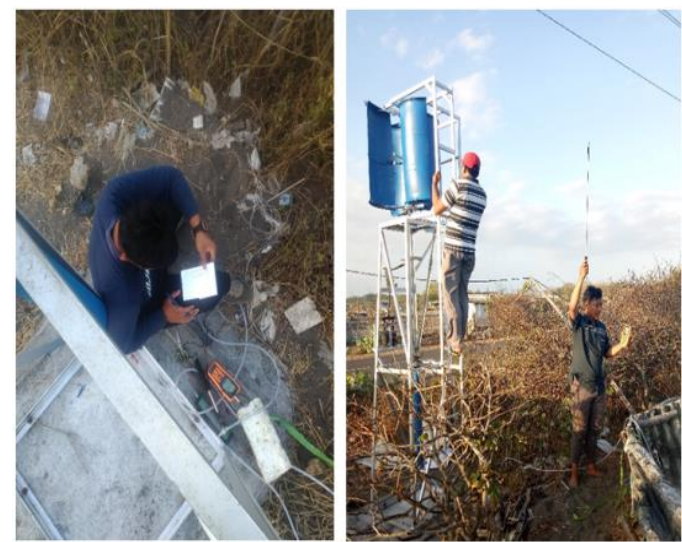

Fig 3. Data measurement in the field 


\subsection{Analysis System}

Data analysis are process to determine and arrange the data systematically that obtained from interviews, data field acqusition, and other sources, so that it is easy to understanding and what we have had could have been informed to others [4].

Measurement data such as wind speed and rotational data that have been measured by then it is used to obtain air flow rate in the compressor by varying the arm length. It is given by

$$
Q=V \times n
$$

where $\mathrm{Q}$ is air flow rate in $\mathrm{m}^{3} /$ minutes, $\mathrm{V}$ is volume in $\mathrm{m}^{3}$, and $\mathrm{n}$ is speed rotation of windmill in rpm.

In this reasearch, we use two compressor which have same type so that they have the same volume as well. The volume can be obtained by following equation,

$$
V=\pi\left(\frac{d}{2}\right)^{2} \times L=\pi r^{2} \times L
$$

Where $L$ is arm lenght of compressor in $\mathrm{cm}, d$ is diameter in $\mathrm{cm}, r$ is radius in $\mathrm{cm}$, and $\pi$ is contant that is $22 / 7$.

Its begin with calculate volume and air flow rate for one compressor, by then for two compressors. these two compressors are obtained by installing a series of two compressors in the windmill structure.

\section{Result and Discussions}

\section{$3.16 \mathrm{~cm}$ arm length of compressor drive}

By using equation (1) \& (2), we can estimate volume and air flow rate values and the result is shown in Table 1.

\begin{tabular}{|c|c|c|c|c|c|c|}
\hline \multicolumn{3}{|c|}{ Length of arm, $L=6 \mathrm{~cm}$} & \multicolumn{2}{|c|}{1 compressor } & \multicolumn{2}{|c|}{2 compressor } \\
\hline $\begin{array}{l}\text { Wind } \\
\text { Speed } \\
(\mathrm{m} / \mathrm{s})\end{array}$ & $\begin{array}{l}\text { Diameter, } \\
\text { d (cm) }\end{array}$ & $\begin{array}{c}\text { Rotational } \\
\text { Speed, } \mathbf{n} \\
(\mathbf{r p m})\end{array}$ & $\begin{array}{c}\text { Volume, } \mathrm{V} \\
\left(\mathrm{cm}^{3}\right)\end{array}$ & $\begin{array}{c}\text { Air Flow } \\
\text { Rate, } \mathbf{Q} \\
\left(\mathrm{cm}^{3} / \text { minutes }\right)\end{array}$ & $\begin{array}{c}\text { Volume, } \\
\left(\mathrm{cm}^{3}\right)\end{array}$ & $\begin{array}{c}\text { Air Flow } \\
\text { Rate, } \mathbf{Q} \\
\left(\mathrm{cm}^{3} / \text { minutes }\right)\end{array}$ \\
\hline 1.5 & \multirow{6}{*}{3.81} & 30 & \multirow{6}{*}{68,73} & 2051.1 & \multirow{6}{*}{136.74} & 4102.2 \\
\hline 2 & & 35 & & 2392.95 & & 4785.9 \\
\hline 2.5 & & 45 & & 3076.65 & & 6153.3 \\
\hline 3 & & 55 & & 3760.35 & & 7520.7 \\
\hline 3.5 & & 64 & & 4375.68 & & 8751.36 \\
\hline 4 & & 75 & & 5127.75 & & 10255.5 \\
\hline
\end{tabular}

Table 1. Measurement Air Flow Rate For 6 Cm Arm Length Of Compressor

Conversion data in Table I into graphic that show comparison of wind speed to air flow rate is ilustrated in Fig. 4. 


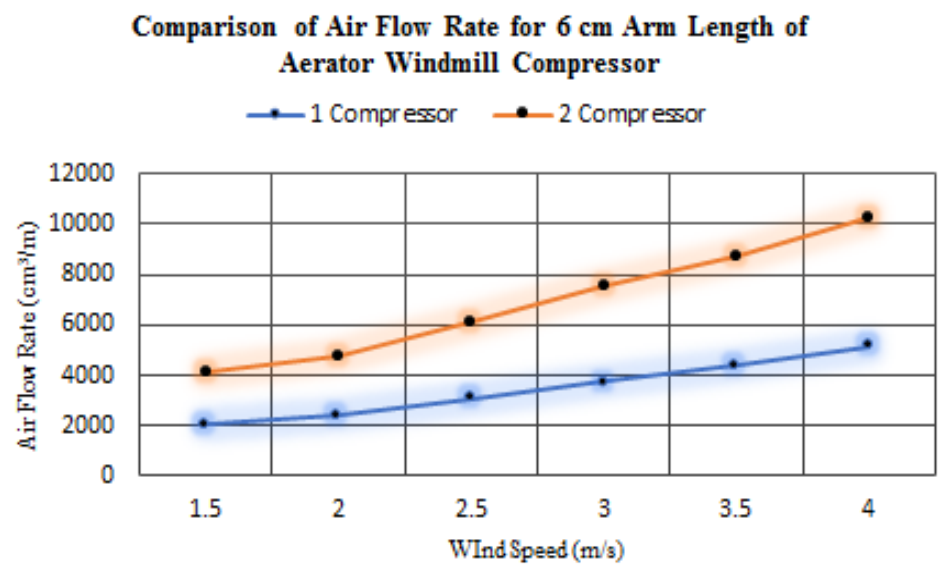

Fig 4. Example of a figure caption. (figure caption)

Both compressors are shown the same graphical trend where air flow rate increases with rising of the wind speed. Maximum of air flow rate for 1 compressor with $4 \mathrm{~m} / \mathrm{s}$ wind speed is approximately $5127,75 \mathrm{~cm}^{3} /$ minutes while using 1 compressor, while for using 2 compressors with the same wind speed it is round $10255,5 \mathrm{~cm}^{3} /$ minutes. Furthermore, Air flow speed for 2 compressors is approximately 50\% much higher than using only 1 compressor. This means more air bubbles are produced to meet a certain pond area. For this reason, a number of compressors is needed.

\section{$3.211 \mathrm{~cm}$ arm length of compressor drive}

Using the same technique in the section before, we could estimate volume and air flow rate values for 11 arm length of compressor drive. The result is given in Table 2.

Table 2. Measurement Air Flow Rate For $11 \mathrm{Cm}$ Arm Length Of Compressor

\begin{tabular}{|c|c|c|c|c|c|c|}
\hline \multicolumn{3}{|c|}{ Length of arm, $L=11 \mathrm{~cm}$} & \multicolumn{2}{|c|}{1 compressor } & \multicolumn{2}{|c|}{2 compressor } \\
\hline $\begin{array}{l}\text { Wind } \\
\text { Speed } \\
(\mathbf{m} / \mathbf{s})\end{array}$ & $\begin{array}{l}\text { Diameter, } \\
\text { d (cm) }\end{array}$ & $\begin{array}{l}\text { Rotational } \\
\text { Speed, } n \\
\text { (rpm) }\end{array}$ & $\begin{array}{l}\text { Volume, V } \\
\quad\left(\mathrm{cm}^{3}\right)\end{array}$ & $\begin{array}{c}\text { Air Flow } \\
\text { Rate, } Q \\
\left(\mathrm{~cm}^{3} / \mathrm{minutes}\right)\end{array}$ & $\begin{array}{l}\text { Volume, V } \\
\quad\left(\mathrm{cm}^{3}\right)\end{array}$ & $\begin{array}{c}\text { Air Flow } \\
\text { Rate, } Q \\
\left(\mathrm{~cm}^{3} / \text { minutes) }\right.\end{array}$ \\
\hline 1.5 & & 30 & & 3760.5 & & 7521 \\
\hline 2 & & 35 & & 4387.25 & & 8774.5 \\
\hline 2.5 & 381 & 45 & & 5640.75 & & 11281.5 \\
\hline 3 & 3.81 & 55 & 125.35 & 6894.25 & 250.1 & 13788.5 \\
\hline 3.5 & & 64 & & 8022.4 & & 16044.8 \\
\hline 4 & & 75 & & 9401.25 & & 18802.5 \\
\hline
\end{tabular}

Fig.5 shows the graphic of comparison of of wind speed to air flow rate that represented in Table II. 


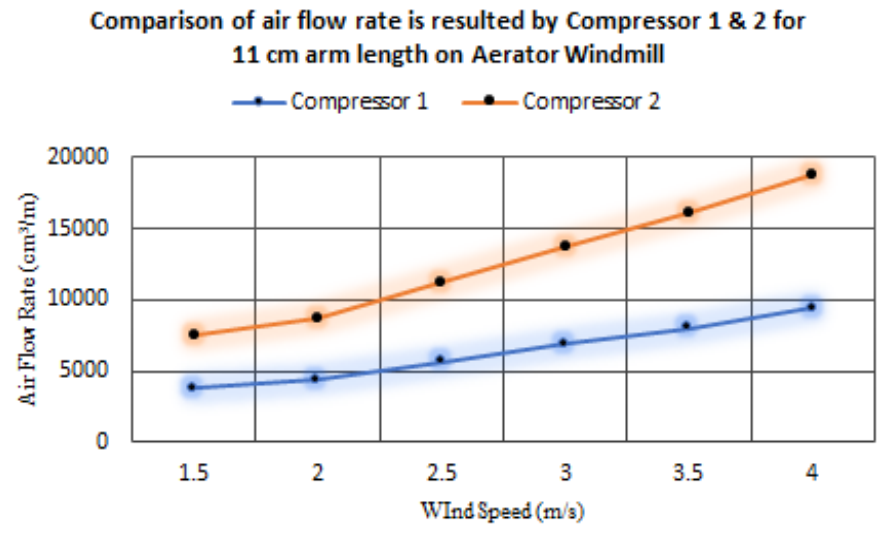

Fig 5. Example of a figure caption. (figure caption)

It is shown on the graphic above that air flow rate for both one compressor or two compressors is increased proportinally with wind speed rising. The value of air flow rate of 11 arm length compressor drive is almost twice than it was given in 6 arm length that is 9401.25 $\mathrm{cm}^{3} /$ minutes for 1 compressor and $18802.5 \mathrm{~cm}^{3} /$ minutes for two compressors respectively. Increasing value is around $50 \%$ for 11 arm length of compressor drive.

Approximately 45,5\% increasing of air flow rate value compared that was given for 6 arm length compressor drive. This means that there will be more air bubbles produced by the airstone with the longer arm of the compressor drive and the large number of parallel compressors installed into the windmill structure.

\section{Conclution}

Based on the analysis that has been carried out, it can be concluded that the longer the arm of the compressor drive and the more the number of compressors installed in parallel, the greater the air flow produced.

For 6 arm length of compressor drive, maximum of air flow rate for 1 compressor with 4 $\mathrm{m} / \mathrm{s}$ wind speed is approximately $5127,75 \mathrm{~cm} 3 /$ minutes while using 1 compressor, while for using 2 compressors with the same wind speed it is round 10255,5 cm3/minutes. Meanwhile, for the value of air flow rate of 11 arm length compressor drive is almost twice than it was given in 6 arm length that is $9401.25 \mathrm{~cm}^{3} /$ minutes for 1 compressor and $18802.5 \mathrm{~cm}^{3} /$ minutes for two compressors of the same wind speed $4 \mathrm{~m} / \mathrm{s}$. There is a $45 \%$ increase from previously obtained.

Acknowledgment. This work is supported by PKM and internal Grants for product design and technology research from RISTEK DIKTI and STTNAS YOGYAKARTA year 2018 for helping society to solve their problem. We are grateful for the financial support so that the research could be proceed smoothly. 


\section{References}

[1] H. S. Tampangallo, B. R. Suwoyo. Suryanto, "Pengaruh Penggunaan Kincir Sebagai Sumber Arus Terhadap Performansi Udang Vaname (Litopenaeus Vannamei) Pada Budidaya Sistem Super Intensif," Pros. Forum Inov. Teknol. Akuakultur, p. 353, 2014.

[2] F. V. Konig, Windenergie in Praktischer Nutzung Räder, Rotoren, Mühlen, Windkraftwerke, 2 ed. Munchen: Udo Pfriemer, 1976.

[3] Wikipedia, "Tachometer," 2017. [Online]. Available: https://id.wikipedia.org/wiki/Tachometer. [Accessed: 10-Aug-2018].

[4] Sugiyono, Metode Penelitian Kuantitatif, Kualitatif dan R\&D, 19 ed. Bandung: Alfabeta, 2013. 